\title{
JAROSLAW GRYZ
}

Akademia Sztuki Wojennej

ORCID: 0000-0001-6671-2391

\section{Znaczenie migracji ludności dla bezpieczeństwa państw wspólnoty transatlantyckiej}

\author{
The importance of migration \\ for the security of the transatlantic community
}

\begin{abstract}
The purpose of this article is to demonstrate the importance of the migration of people and its selected forms for the international and national security of the transatlantic community located on the European and North American continents. The thesis is that the phenomenon of migration in the first half of the $21^{\text {st }}$ century increasingly determines the security of these countries, including transatlantic ties and international activities undertaken or not in this formula. Along with political, military, social and economic issues, migration will determine the policy of the transatlantic community. It becomes the leading domain for international activities undertaken individually and collectively by the countries of the European Union and the North Atlantic Alliance. Moreover, the discourse between the supporters and opponents of migration not only affects the shape of the migration policies of these entities, but also those of the areas adjacent to NATO and the EU. The analysis included in this articles focuses on the period between 2015 and 2019 and prospects up to 2030.
\end{abstract}

Keywords: migration, transatlantic community, international security, European Union, NATO

Słowa kluczowe: migracje ludności, wspólnota transatlantycka, bezpieczeństwo międzynarodowe, Unia Europejska, NATO

\section{Wprowadzenie}

Migracje ludności do państw Unii Europejskiej i Sojuszu Północnoatlantyckiego z obszarów przyległych do kontynentów europejskiego i północnoamerykańskiego, a także państw sąsiadujących stały się dla nich jednym 
z fundamentalnych wyzwań pierwszej połowy XXI w. ${ }^{1} \mathrm{~W}$ sferze bezpieczeństwa międzynarodowego wynika to $\mathrm{z}$ kilku równocześnie zachodzących zjawisk. Pierwszym jest transparentność granic i kontrola nad ich przekraczaniem $^{2}$. Drugie to ochrona ładu międzynarodowego na styku granic państw Unii Europejskiej, Sojuszu Północnoatlantyckiego oraz przylegających do nich obszarów ${ }^{3}$. Trzecim jest zapewnienie bezpieczeństwa wewnętrznego państw wspólnoty transatlantyckiej, na które wywierają wpływ migracje ludności ${ }^{4}$. Czwartym - zagadnienia tożsamości indywidualnej i zbiorowej, charakteru i sposobów integracji społecznej migrującej ludności na tle starzejących się społeczeństw ${ }^{5}$. Piątym wreszcie - praktyczne zapewnienie bezpieczeństwa narodowego i międzynarodowego, przede wszystkim przy wykorzystaniu metod rozwoju ekonomicznego i zapewniania praw człowieka ${ }^{6}$.

W przypadku Europy i Ameryki Północnej wskazane zjawiska mają odmienny charakter ${ }^{7}$. Na każdym z tych kontynentów migracje cechują się innymi formami społecznymi, kulturowymi i organizacyjnymi, a przede wszystkim mają odmienne znaczenie polityczne. Zróżnicowanie tego rodzaju występuje także pomiędzy Stanami Zjednoczonymi i Kanadą. Granica lądowa USA z Meksykiem implikuje odmienną postać migracji i jej kontroli niż w przypadku Kanady. Do pewnego stopnia odzwierciedla to sytuację geopolityczną na granicach Unii Europejskiej - zarówno państw granicznych, jak i tych położonych w głębi kontynentu.

Znaczenie migracji ludności dla bezpieczeństwa państw wspólnoty transatlantyckiej szczególnie ostro zarysowało się w 2015 r., na kanwie masowego exodusu z obszarów przyległych geograficznie do Unii Europejskiej i Sojuszu

Strategic foresight analysis. 2017 Report, NATO, [b.m.r.w.], s. 35-37.

2 D. Fiott, R. Parkes, Protecting Europe. The EU's response to hybrid threats, European Union Institute for Security Studies, April 2019 (Chaillot Paper, 151), s. 16-21.

3 R. Gowan, Bordering on crisis: Europe, Africa, and a new approach to crisis management, European Council of Foreign Relations, April 2017 (Policy Brief), s. 1-11.

4 K.M. Greenhill, The weaponisation of migration, [w:] Connectivity wars. Why migration, finance and trade are the geo-economic battlegrounds of the future, ed. M. Leonard, European Council of Foreign Relations, 2016, s. 77-80.

5 Multiple Futures Project. Navigating towards 2030. Final report, NATO, April 2019, s. $20-21$.

6 Migration and 2030 Agenda. A guide for practitioners, International Organization for Migration, Geneva 2018, s. 17-115.

7 Według badań Gallupa z 2015 r. 52 proc. Europejczyków uważało, że migrację do Europy należy zmniejszyć, a w tym samym czasie 62 proc. badanych Amerykanów twierdziło, że napływ migrantów do USA powininen wzrosnąć. Negatywny trend oceny tego zjawiska w Europie pogłębił się w 2016 r. Global migration indicators 2018, Global Migration Data Analysis Centre, International Organization for Migration, Berlin 2018, s. 48-49. 
Północnoatlantyckiego ${ }^{8}$. Zderzyły się wówczas dwie formy argumentacji i towarzyszące im do dziś narracje: humanitarna, biorąca w obronę prawa jednostki i jej godność oraz głosząca konieczność zapewnienia jej bezpiecznej egzystencji i rozwoju, a także ta, która wskazuje, że dzielenie się tymi dobrami ma charakter ograniczony co do miejsca i czasu. Nie wszyscy i nie wszędzie mogą się cieszyć dobrobytem, a jego postać powinna być współdzielona przez formy współpracy międzynarodowej promujące rozwój, ład i bezpieczeństwo. W założeniu tej drugiej dzięki takiej formule działań możliwe będzie zapewnienie ochrony indywidualnej i zbiorowej, państwa prawa, egzystencji i rozwoju w czasie, i to zarówno w Unii Europejskiej i Sojuszu Północnoatlantyckim, jak też na obszarach przyległych, przede wszystkim na Bliskim Wschodzie oraz w Afryce Północnej i Równikowej.

Wskazane zderzenie sposobów pojmowania problemu migracji, a także krótkotrwały kryzys w tym obszarze związany z transparentnością granic UE wywołały frustrację zwykłych obywateli, społeczeństw oraz ich elit. Dyskurs polityczny związany był przede wszystkim z charakterem wielokulturowości ${ }^{9}$ oraz decyzjami kanclerz Niemiec Angeli Merkel co do Willkommenspolitikpolityki otwartych drzwi dla imigrantów. Do dziś istnieją różnice w ocenie tego zjawiska wśród państw członkowskich Unii, szczególnie między członkami Grupy Wyszehradzkiej i pozostałymi. Ich rezultatem jest zaś m.in. sprzeciw Wielkiej Brytanii wobec obrania drogi wytyczanej przez Berlin i Brukselę, który przybrał postać debaty w sprawie opuszczenia Unii Europejskiej oraz referendum przeprowadzonego w tej sprawie w 2016 r. Tłem dyskursu na temat migracji prowadzonego w różnego typu mediach stało się wiele ważnych pytań: W jakim położeniu znaleźliśmy się my, Europejczycy, i co na to nasi partnerzy zza oceanu - Stany Zjednoczone i Kanada? Jakie są nasze społeczeństwa, co je łączy i dzieli w zakresie podejścia do migracji ze słabo rozwiniętych regionów naszej planety? Jakie działania powinniśmy podejmować tu i teraz oraz w bliższej i dalszej przyszłości, by w odpowiedni sposób podejść do tego zagadnienia po obu stronach Atlantyku?

W debacie na temat migracji na poziomie narodowym i instytucji międzynarodowych, ONZ, Unii Europejskiej, a także NATO pojawiły się liczne, często nakładające się na siebie lub też wzajemnie wykluczające się kwestie. Czy charakter zjawiska migracji powinny określać państwa narodowe, czy też tak

8 R. Parkes, Nobody move! Myths of the EU migration crisis, EU Institute for Security Studies, December 2017 (Chaillot Papers, 143), s. 35-138.

9 L. Aggestam, Ch. Hill, The challenge of multiculturalism in European foreign policy, „International Affairs” 2008, vol. 84, issue 1, s. 97-114. 
jak w przypadku Europejczyków - ponadnarodowa organizacja, jaką jest Unia Europejska? Jak mamy postępować z migrantami, gdy część z nich odrzuca liberalną tradycję humanitarną w imię swoich dotychczasowych, hermetycznych politycznie czy kulturowo albo jeszcze innych wyobrażeń? Czy i gdzie postawimy nieprzekraczalne granice dla bezpieczeństwa jednostek i zbiorowości w procesach integracji i dezintegracji liberalnych społeczeństw demokratycznych? Pomijany jest przy tym rdzeń problemu, niezwykle trudny i niewygodny dla polityków - jak w sieciowo i instytucjonalnie zorganizowanych wspólnotach międzynarodowych chcemy żyć z udziałem migrantów, a w przypadku państw Unii Europejskiej - na jakich warunkach tworzących wspólną przestrzeń życia społecznego? Powyższe pytania, jak i wiele innych podobnych, jawią się jako coraz bardziej fundamentalne w XXI w.

Podnoszone w debacie publicznej argumenty za migracją ludności i przeciw niej, dotyczące jej form, a na tym tle formuły związków między państwami i ich społeczeństwami po obu stronach Atlantyku, są niezwykle istotne. Wpływają na pojmowanie tego zjawiska w kontekście bezpieczeństwa narodowego i międzynarodowego ${ }^{10}$. W tym drugim przypadku rzecz dotyczy polityki państw wobec obszarów przyległych ${ }^{11}$. Szczególne znaczenie mają tutaj najważniejsze problemy związane z migracją ludności:

- formy i formuły globalnego, sieciocentrycznego zarządzania bezpieczeństwem narodowym i międzynarodowym ${ }^{12}$;

- związki między migracją a szybko zmieniającymi się poziomami i rodzajami powiązań transnarodowych ${ }^{13}$;

- związki między migracją a ekstremizmem i terroryzmem, ruchami społecznymi, partiami politycznymi oraz formami związanej z tym polityki wewnętrznej i międzynarodowej ${ }^{14}$;

- charakter tożsamości indywidualnej i zbiorowej ${ }^{15}$;

10 R. McNeil, Migrants and the media: what shapes the narratives on immigration in different countries, „The Conversation”, 26 IV 2019.

11 T. Abderrahim, Pushing the boundaries. How to create more effective migration cooperation across the Mediterranean, European Council of Foreign Relations, January 2019 (Policy Brief), s. 2-30.

12 A.M. Kjær, Rzadzenie, Sic!, Warszawa 2009, s. 72-116.

13 T. Strik, The global approach to migration and mobility, „Groningen Journal of International Law" 2017, vol. 5, issue 2, s. 316-317.

14 E. Kessels, Ch. Nemr, Countering violent extremism and development assistance identifying synergies, obstacles, and opportunities, Global Center on Cooperative Security, February 2016 (Policy Brief), s. 1-8.

15 T. Lindhard, The search for unity beneath our cultural differences, [w:] Cross-cultural dialogue as a conflict management strategy, ed. J.M. Ramírez, G. Abad-Quintanal, Springer, 2018, s. 61-67. 
- rozwój społeczny i jego poziom w poszczególnych regionach planety;

- sposoby i charakter prowadzonych działań militarnych i niemilitarnych, tworzących bądź destabilizujących ład międzynarodowy.

Pojmowanie tych zagadnień i ich wzajemne przenikanie tworzy obecną wykładnię problematyki migracji ludności ze słabo do wysokorozwiniętych obszarów naszej planety i położonych tu państw wspólnoty transatlantyckiej. Ponadto określa ich stanowiska w wymiarze narodowym ( $\mathrm{tj}$. partii politycznych, ruchów obywatelskich oraz zwykłych ludzi) i międzynarodowym (organizacji i instytucji) ${ }^{16}$. Wykładnia ta implikuje przyjmowane rozwiązania normatywne i organizacyjne oraz stosowanie tych, które już istnieją.

\section{Wpływ migracji na bezpieczeństwo państw wspólnoty transatlantyckiej}

Współczesne bezpieczeństwo państw wspólnoty transatlantyckiej w wymiarze narodowym i międzynarodowym określone przez pryzmat migracji ma niezwykle zróżnicowaną postać. Zależy ona od wielu czynników i zmiennych.

1. Państwa położone na dwóch różnych kontynentach nie posługują się tożsamą wykładnią. Reprezentują więc odmienne podejścia i sposoby postępowania wobec migrantów pomimo obowiązywania wspólnej Powszechnej Deklaracji Praw Człowieka.

W przypadku państw Unii Europejskiej i Sojuszu Północnoatlantyckiego nienależących do strefy Schengen ${ }^{17}$ zasadniczą kwestią pozostaje transparentność granic i kontrola nad ich przekraczaniem. Od wdrożenia w 1999 r. traktatu z Amsterdamu UE przyjęła szereg służących temu instrumentów, wśród których należy wymienić współpracę z państwami trzecimi w zakresie zarządzania migracją, granicami i azylem w ramach globalnego podejścia do kwestii migracji i mobilności ${ }^{18}$, a ponadto wzmacnianie granic państw trzecich przez kontrole, politykę wizową, przyjmowanie nielegalnych migrantów z takimi zachętami ze strony Unii, jak korzyści handlowe, ułatwienia wizowe lub wsparcie finansowe ${ }^{19}$. Kierując się zasadami prawa do ochrony międzynarodowej, UE przyjęła wspólną politykę azylową i migracyjną. Migranci otrzymują dzięki niej prawo pobytu wraz z przynależnymi mu formami ochrony

16 A. Menon, J.-P. Salter, Brexit: initial reflections, „International Affairs” 2016, vol. 92, issue 6, s. 1301-1317.

17 Państwa NATO ubiegające się o członkostwo w strefie Schengen to: Bułgaria, Chorwacja, Cypr, Rumunia i Słowenia.

18 Globalne podejście do kwestii migracji i mobilności, Komisja Europejska, KOM(2011) 743 wersja ostateczna, Bruksela, 18 XI 2011.

19 T. Strik, The global approach..., s. 310-326. 
zawartymi w Karcie Praw Podstawowych Unii Europejskiej. Wśród należących do niej państw przedmiotem dyskursu politycznego pozostają kwestie nadania statusu uchodźcy w państwie przyjmującym, opieki i wreszcie readmisji migrantów niespełniających warunków pobytu na terenie Wspólnoty. Rzecz dotyczy przy tym wymiaru wewnętrznego jej polityki.

Odnośnie do wymiaru zewnętrznego Tineke Strik wskazuje, że między polityczną wolą działania poza granicami Unii a gwarantowanymi w niej prawami dla imigrantów kryją się pułapki, w które wpada wspólna polityka zagraniczna i bezpieczeństwa w konfrontacji z Karta Praw Podstawowych. Pierwszą z nich jest zewnętrzny wymiar polityki migracyjnej. Kwestia przyjmowania migrantów w kontrze do ich powstrzymywania poza granicami UE zderza się ze stanowiskami narodowymi poszczególnych państw członkowskich. Implikuje to porozumienia Unii z państwami trzecimi, m.in. w zakresie celów jej polityk zewnętrznych w postaci utrzymania stabilności, współpracy regionalnej, praworządności, pokoju i bezpieczeństwa oraz wzrostu gospodarczego. Polityki te uzależnione są w wymienionych obszarach od walki z nielegalną migracją z regionów przyległych do kontynentu europejskiego. Zagadnienia praw migrantów i form migracji stają się pochodną uzgodnień zawieranych z tymi państwami w innych kwestiach ${ }^{20}$. Implikuje to zjawisko migracji, jego oceny na poziomie instytucji UE i jej państw członkowskich.

W przypadku państw północnoamerykańskich problem migracji ma odmienne uwarunkowania ${ }^{21}$. Wynikają one przede wszystkim z tożsamości kulturowej migrantów oraz ich chrześcijańskich korzeni, a także charakteru wspólnot, z których pochodzą ${ }^{22}$. Nie są przy tym narażeni na radykalizację i nie spotykają się z przejawami terroryzmu, jak ma to niekiedy miejsce w przypadku migrantów udających się do Europy z Afryki czy Bliskiego Wschodu ${ }^{23}$. Niemniej jednak formy migracji do USA i Kanady determinowane są podobnie jak w przypadku Unii Europejskiej poziomem rozwoju państw położonych na południu. Mające powstrzymać migrację działania w postaci uszczelnienia amerykańskiej granicy i zapowiedzi nałożenia na Meksyk kar

20 Tamże.

21 R. Nunn, J. O’Donnell, J. Shambaugh, A dozen facts about immigration, The Hamilton Project, October 2018, s. 6-14.

22 Ch. Joppke, Successes and failures of Muslim integration in France and Germany, [w:] Bringing outsiders in. Transatlantic perspectives on immigrant political incorporation, ed. J.L. Hochschild, J.H. Mollenkopf, Cornell University Press, 2009, s. 115-128.

23 M. Mandelbaum, Migration and its discontents. The impacts of immigration: Europe vs. America, „The American Interest”, 13 VI 2018. 
gospodarczych są częścią problemu ${ }^{24}$, a nie jego rozwiązaniem ${ }^{25}$. Podobnie rzecz wygląda w przypadku prawa pobytu i readmisji. Pomimo porozumień handlowych, w tym Północnoamerykańskiej Strefy Wolnego Handlu, na południe od Rio Grande dobrobyt i ochrona praw człowieka są pojęciami względnymi. Ubóstwo, przemoc i przestępczość zorganizowana, a niekiedy opresyjne rządy, jak w Nikaragui czy Wenezueli, są elementami codzienności i rzadko zdarzają się odstępstwa od tego standardu. Co ciekawe, jest to wspólny mianownik sąsiadów wspólnoty transatlantyckiej położonych na obu brzegach oceanu. Jej członkowie mierzą się w związku z tym z szerszym problemem, obejmującym przede wszystkim kwestie rozwoju gospodarczego, ochrony środowiska naturalnego oraz praw człowieka, odmiennie definiowanych w różnych kulturach i cywilizacjach. Wspólny mianownik nie oznacza dla państw wspólnoty transatlantyckiej jednakowego podejścia, jakie istnieje w przypadku polityki bezpieczeństwa i obrony w ramach Sojuszu Północnoatlantyckiego. Warto wskazać na ten kontekst sytuacyjny jako zasadniczy imperatyw podejścia państw UE i NATO do zjawiska migracji w skali planety czy poszczególnych regionów.

2. Ochrona ładu międzynarodowego na styku granic państw Unii Europejskiej, Sojuszu Północnoatlantyckiego oraz przyległych obszarów stanowi istotne wyzwanie z pogranicza bezpieczeństwa, rozwoju społecznego, politycznego, kulturowego, ekonomicznego i innych. Determinuje ona również postać stosunków transatlantyckich i sposobów ich realizacji z innymi niż UE i NATO organizacjami oraz państwami.

Według statystyk World migration report 2018 w 2000 r. liczba migrantów wynosiła 172703309 osób, co stanowiło 2,8 proc. światowej populacji ${ }^{26}$. W 2015 r. było to już 243700236 osób, czyli 3,3 proc. ludzkości. Według portalu „Wordometers” w 2000 r. populacja zamieszkująca Ziemię liczyła 6302149639 osób, a w 2015 - 7383008 82027. Obiektywnie rzecz biorąc, utrzymywanie się wzrostowego trendu migracji związane jest z liczbą ludzi zamieszkujących planetę. Dla państw wspólnoty transatlantyckiej konsekwencją takiego stanu rzeczy jest nasilenie zjawiska migracji, co w aspekcie ich

24 A. Swanson, Trump's tariff threat sends Mexico, lawmakers and businesses scrambling, „The New York Times”, 31 V 2019.

25 M.D. Shear, M. Jordan, M. Fernandez, The U.S. immigration system may have reached a breaking point, „,The New York Times”, 10 IV 2019.

26 World migration report 2018, International Organization for Migration, The UN Migration Agency, Geneva 2018, s. 15.

27 World polulation by year, „Wordometers” [online, dostęp: 20 XI 2019], dostępny w internecie: <http://www.worldometers.info/world-population/world-population-by-year/>. 
bezpieczeństwa stanowi obecnie i w przyszłości jeden z głównych punktów odniesienia dla decydentów politycznych i społeczeństw ${ }^{28}$. Biorąc pod uwagę wskazany trend, jego postać określoną migracjami społeczności odmiennych kulturowo i cywilizacyjnie (m.in. z uwagi na jakość życia w miejscu zamieszkania, nierówności społeczne, demografię, przemoc oraz konflikty wewnętrzne, zmiany środowiska naturalnego, kulturę, religię, pracę, studia oraz wiele innych czynników), należy przyjąć, że jest on i będzie czynnikiem stałym. Od zamachów terrorystycznych z 11 września 2001 r. wyraźnie implikuje on bezpieczeństwo międzynarodowe i wewnętrzne tworzących więzi transatlantyckie państw Sojuszu Północnoatlantyckiego i Unii Europejskiej.

3. Zapewnienie bezpieczeństwa wewnętrznego państw wspólnoty transatlantyckiej, na które wpływają migracje ludności, stanowi jeden z kluczowych elementów panującego w nich ładu.

Zagadnienia osobowości i przynależności społecznej w sieciocentrycznym świecie są dziś ściśle powiązane z zagadnieniami wolności indywidualnej i zbiorowej oraz jej ekspresji, a także etniczności i narodowości ${ }^{29}$, budowanych w tym kontekście norm państw czy organizacji międzynarodowych. Wskazana kolejność nie jest przypadkowa. Elementy te oddziałują na siebie wzajemnie, stanowiąc rdzeń polityki państw w aspekcie bezpieczeństwa indywidualnego i zbiorowego. Idea tego związku - wolności i bezpieczeństwa obejmując zagadnienia tożsamości, tworzy ich wykładnię. Stałym kontekstem sytuacyjnym dla państw wspólnoty transatlantyckiej jest przy tym fakt, że idea ta ciągle weryfikowana jest $\mathrm{w}$ coraz bardziej złożonych formach więzi społecznych $^{30}$. Postać tych więzi poddawana jest zmianom w procesach informacyjnych dyktowanych oceną danego zdarzenia lub zjawiska społecznego oraz jego następstw. Dwie kwestie mają tu zasadnicze znaczenie i są punktem odniesienia dla bezpieczeństwa państw wspólnoty transatlantyckiej w aspekcie zjawiska migracji ludności.

Pierwszą jest świadomość grupowa. Związek między jej charakterem a przekształcaniem w czasie $\mathrm{w}$ dobie wykorzystywania informacji jako instrumentu wpływu (również w aspekcie dezinformacji) stanowi obecnie jeden z rdzeni bezpieczeństwa państw wspólnoty transatlantyckiej ${ }^{31}$. Aktywne od-

28 A. Lebovich, Halting ambition: EU migration and security policy in the Sahel, European Council of Foreign Relations, September 2018 (Policy Brief), s. 8-16.

29 T. Delpech, Powrót barbarzyństwa w XXI wieku, NADIR, Warszawa 2008, s. 59-106.

30 A.M. Kjær, Rządzenie..., s. 29-116.

31 S. Macdonald, Propaganda and information warfare in the twenty-first century. Altered images and deception operations, Routledge, London-New York 2007, s. 24-33. 
działywanie na niego stanowi zarówno o zdolności tych państw do zapewnienia ładu społecznego, jak i jego projekcji na przestrzeni określonej granicami ich wpływu ${ }^{32}$. Od czasów rewolucji amerykańskiej można było obserwować kształtowanie formuły tego związku w relacjach państw położonych po obu stronach Atlantyku. Działo się to zarówno w okresach wojen i towarzyszącej im mobilizacji, jak i w dobie pokoju po zimnej wojnie. Szczególnym przykładem tego związku jest powstanie i ewolucja Wspólnot Europejskich, a następnie Unii Europejskiej, możliwe dzięki zaangażowaniu Stanów Zjednoczonych po drugiej wojnie światowej. Pod wpływem tych organizacji, a zarazem pod amerykańskim parasolem ochronnym, państwa zachodnioeuropejskie zdołały stworzyć struktury ścisłych powiązań międzynarodowych bazujące na wspólnej, spójnej aksjologicznie wykładni politycznej i społecznej.

Procesy afiliacji tożsamości indywidualnej i grupowej jednoznacznie wskazują na dwa aspekty mające szczególne znaczenie dla bezpieczeństwa państw wspólnoty transatlantyckiej. Pierwszym jest fakt, że występujące od początku lat dziewięćdziesiątych XX w. założenie o stopniowym narastaniu niebezpieczeństwa związanego z kulturą i tożsamością oraz kształtowaniu ich jako narzędzia przemocy w polityce, a niekiedy w strategii państw sprawdza się $\mathrm{w}$ czasie ${ }^{33}$. Wpisują się $\mathrm{w}$ to także próby wpłynięcia na przebieg wyborów prezydenckich w Stanach Zjednoczonych w 2016 r. oraz wyborów parlamentarnych we Francji i Niemczech w 2017. Drugim aspektem jest współczesne zjawisko zmiany formuły tożsamości, które staje się kluczowe dla liberalnej demokracji i towarzyszącej jej gospodarki kapitalistycznej. Jest ono centralnym punktem odniesienia dla indywidualnych wolności oraz zabezpieczających je praw, przede wszystkim tych, które stały się kluczowe $\mathrm{w}$ procesach integracji atlantyckiej i europejskiej.

Druga kwestia to zjawisko odrzucania wartości świata Zachodu, którego przejawy można zaobserwować na obszarach geograficznych wokół UE oraz w niej samej. Jest to radykalizacja niektórych społeczności - zamkniętych, odrzucających otwartość na poglądy innych oraz poszanowanie praw człowieka. Na kontynencie europejskim przejawem takich postaw są no go zones czy non governed zones. Atakowanie w nich przedstawicieli społeczeństw państw, do których przybyli zamieszkujący je ludzie, jest normą, a prześladowania osób nieakceptujących obowiązujących tam reguł - przejawem tego stanu

32 J.L. Hochschild, J.H. Mollenkopf, Modeling immigrant political incorporation, [w:] Bringing outsiders in..., s. 15-30.

33 S.P. Huntington, The clash of civilizations?, „Foreign Affairs” 1993, vol. 72, No. 3, s. 22-29. 
rzeczy $^{34}$. Lista europejskich państw, w których istnieją tego rodzaju obszary, jest długa: rozciągają się one od Skandynawii po Europę Południową, obejmując m.in. Wielką Brytanię, Szwecję, Niemcy, Belgię i Francję. Zasadniczą kwestią jest dialog jako narzędzie powstrzymania ekstremizmu, a niekiedy zjawiska terroryzmu ${ }^{35}$. Podobnie rzecz wygląda w przypadku społeczności, których radykalizacja umożliwia szerzenie propagandy oraz prowadzenie działań ekstremistycznych i terrorystycznych ${ }^{36}$.

4. Zagadnienia indywidualnej i zbiorowej tożsamości oraz charakteru i sposobów integracji społecznej migrantów stanowią element decydujący o charakterze związków społecznych.

W XXI stuleciu przywiązanie danej grupy społecznej do tożsamości, natura więzi mentalnych, pielęgnowanie ich $\mathrm{w}$ ramach wyabstrahowanego archetypu oraz schematy: ja, my, oni, wy (inni), nadal odgrywają fundamentalną rolę w kontekście indywidualnego i zbiorowego bezpieczeństwa państw wspólnoty transatlantyckiej. Schemat ten - choć podlegający zmianom, to powielany w czasie - tworzony jest współcześnie i przekształcany pod wpływem bodźców informacyjnych będących przedmiotem różnego rodzaju oddziaływań ${ }^{37}$. Niezależnie od statusu i miejsca pochodzenia społeczeństw państw wspólnoty transatlantyckiej buduje on ich tożsamość w tym samym czasie i w odniesieniu do tych samych informacji, choć różnie interpretowanych i wykorzystywanych. Na ten aspekt warto zwrócić uwagę w kontekście zjawiska migracji. Występuje ono wówczas, gdy mamy do czynienia ze zdynamizowaniem zjawiska koegzystencji różnych społeczności, osiadłych i napływowych, które cechują odmienne formy tożsamości.

Współcześnie możemy zaobserwować, jak określona forma tożsamości staje się narzędziem oddziaływania, zmieniając postać stosunków wewnętrznych i międzynarodowych ${ }^{38}$. Dzięki procesom komunikacji formuła przemocy

34 J.E. Herbst, Forsaken territories? The emergence of Europe's grey zone and Western policy, [w:] The Eastern question Russia, the West, and Europe's grey zone, ed. D. S. Hamilton, S. Meister, Center for Transatlantic Relations, Washington DC 2016, s. 189-192.

35 C.A. Payá-Santos, J.J. Delgado-Morán, P.A. Mazurier, Individual terrorism as a response to the distorted phenomenon of cultural identity, [w:] Cross-cultural dialogue..., s. 34-43.

36 Bin Laden's ,, letter to America”, „The Guardian” [online, dostęp: 22 V 2018], dostępny w internecie: <https://www.theguardian.com/world/2002/nov/24/theobserver>.

37 S. Stryker, P.J. Burke, The past, present, and future of an identity theory, ,Social Psychology Quarterly" 2000, vol. 63, No. 4, s. 284-297.

38 A.A. Gasparini, This is not you! Identity crisis in the 21 st century, [w:] ACHI 2018: The Eleventh International Conference on Advances in Computer-Human Interactions, IARIA, 2018, s. 13-16. 
i agresji kulturowej zagrażająca państwom wspólnoty transatlantyckiej podlega dużo szybszym zmianom. Ma to miejsce w zakresie procesów afiliacji, wywołując gwałtowne zmiany w zakresie bezpieczeństwa wewnętrznego i międzynarodowego ${ }^{39}$. Charakter indywidualnych i zbiorowych wyborów, wielowarstwowość indywidualnej tożsamości oraz jej wpływ na tożsamość zbiorową są dużo bardziej zmienne ${ }^{40}$. W dobie informacji ich selektywny wybór decyduje o przynależności lub odrzuceniu więzów z poszczególnymi wspólnotami. Wybór ten stanowi obecnie klucz do bezpieczeństwa wewnętrznego oraz formuły polityki państw wspólnoty transatlantyckiej w zakresie integralności społeczeństw i zapewniania bezpieczeństwa społecznego.

Oddziaływanie na hierarchię wartości za pomocą idei wolności stanowi fundament bezpieczeństwa politycznego państw wspólnoty transatlantyckiej. Obejmuje ono wszelkiego typu zmiany, w tym adaptację indywidualną i zbiorową wyrażaną kryzysem tożsamości, a niekiedy afiliacją. Należy podkreślić, że sytuacja ta wpływa na formułę działań, które państwa wspólnoty transatlantyckiej podejmują w związku z migracjami ludności w danych okolicznościach. W pespektywie czasu nakłada na decydentów politycznych obowiązek określenia akceptowanej formuły tożsamości i związanych z nią form adaptacji, zarówno w czasie, jak i w ramach danego społeczeństwa. Postać poszczególnych społeczeństw wspólnoty transatlantyckiej, a zarazem jej państw, wskazuje, że niektóre bez większego trudu radzą sobie z wielowarstwowością indywidualnej tożsamości i jej wpływem na tożsamość zbiorową, ale inne mają z tym kłopoty ${ }^{41}$. W wymiarze praktycznym oznacza to, że członkowie danego społeczeństwa potrafią pogodzić własne więzi ze związkami z innymi społeczeństwami czy społecznościami, w tym nowo przybyłymi migrantami ${ }^{42}$. Bariera w tego typu relacjach pojawia się wówczas, gdy kultura afiliacji nie

39 Multiple Futures Project..., s. 20.

40 Truizmem jest tu twierdzenie, że każdy człowiek w mniejszym lub większym stopniu należy jednocześnie do wielu wspólnot: w sferze duchowej - do aksjologicznej, afiliacyjnej, a w zakresie przynależności - do rodziny, przyjaciół i znajomych oraz do stron rodzinnych (miejsca, ulicy, dzielnicy, miasta). Ponadto należy do wspólnoty językowej, kulturowej, państwowej, do grupy rasowej, danej społeczności czy społeczeństwa. Migration theory. Talking across disciplines, ed. C.B. Brettell, J.F. Hollifield, Routledge, New York-London 2013, s. 113-151.

41 Transatlantic trends: mobility, migration, and integration. Key findings from 2014 and selected highlights from transatlantic trends and transatlantic trends. Immigration 2008-13, The German Marshall Fund of the United States, 2014, s. 5-13.

42 I. Bloemraad, A. Korteweg, G. Yurdakul, Citizenship and immigration: multiculturalism, assimilation, and challenges to the nation-state, „Annual Review of Sociology” 2008, vol. 34 , issue 1, s. 155-170. 
jest wykształcona, zostaje przez jedną ze stron zniekształcona lub odrzucona (niekiedy celowo), a w tym miejscu pojawiają się lub występują od początku więzi ograniczonych relacji. W tej postaci są one bardzo podatne na manipulację, i to zarówno na poziomie jednostki, jak i zbiorowości.

Należy podkreślić, że opisana sytuacja dotyczy społeczeństw zamieszkujących demokratyczne państwa wspólnoty transatlantyckiej - ludzi, którzy do nich migrowali lub w nich osiedli. Ekstremalnym przykładem zaburzenia więzi społecznych są ataki terrorystyczne z udziałem osób, które odrzuciły demokratyczny system wartości, wybierając w to miejsce model ekstremistyczny, ograniczony do danej wykładni, społeczności itp. Postać tych więzi z udziałem ludzi, którzy przybyli do społeczeństw otwartych lub też, socjalizując się w nich, odrzucili ich wartości, stanowi dowód na występowanie manipulacji ${ }^{43}$. W przypadku państw wspólnoty transatlantyckiej prawdziwe kłopoty powstają wówczas, gdy tego typu sytuacja nie jest rozpoznana lub z różnych względów, szczególnie politycznych, ignoruje się jej istnienie. Przyczyny takiego stanu rzeczy mogą być bardzo różne - od braku właściwej wiedzy co do sposobu zapewniania bezpieczeństwa wewnętrznego w uwarunkowaniach XXI w., po nieuzasadnioną arogancję poprawności politycznej, która narzuca jedyną właściwą, zafałszowaną w swojej wykładni narrację.

Kluczowym zagadnieniem w kontekście związków między bezpieczeństwem państwa należącego do wspólnoty transatlantyckiej a migracją ludności staje się idea społeczeństwa otwartego - jego formy oraz formuly integralności i wykluczenia, afiliacji ról społecznych, kulturowych i politycznych. Ten aspekt kreacji tego, co idealne, tworzenia i odtwarzania indywidualnych i zbiorowych wyobrażeń o sobie samych, de facto idei samego siebie, jest poddawanym przekształceniom fundamentem współczesnych społeczeństw demokratycznych i ich bezpieczeństwa ${ }^{44}$. Obecnie idea ta generowana jest przez czynnik migracji. Tworzy ona formę kreacji lub rekreacji społeczeństw państw wspólnoty transatlantyckiej. Jej postać jest przy tym niedookreślona $\mathrm{z}$ uwagi na brak wiodącej formuły artykułowanych jako condicio sine qua non adaptowanych wartości indywidualnych i zbiorowych u osób migrujących, jak i przyjmujących imigrantów społeczeństw ${ }^{45}$.

43 J. Gryz, Impact of terrorism on civic society: European Union's case study, „Scientific Journal of Internal Security and Civil Defence: Border Security and Management" 2018, No. 2 (7), s. 64-71.

44 Tamże.

45 „Lud, który przychodzi na miejsce innego ludu, nie jest po prostu przedłużeniem tego drugiego, uzupełnianego kilkoma cechami nowymi. Jest inny, ma pewne nowe właściwości, 
Wskazany aspekt sytuacyjny jest kluczowy dla sposobu pojmowania idei bezpieczeństwa wewnętrznego w społeczeństwach otwartych, sieciocentrycznych. Społeczeństwo nie stanowi jedynie ogółu składających się na nie jednostek, obszaru, na którym osiadły, wykorzystywanych rzeczy i pełnionych czynności, lecz jest sumą idei samego siebie ${ }^{46}$. Pozbawienie migrantów wiodących norm politycznych i zrozumienia dla tożsamości danego społeczeństwa wspólnoty transatlantyckiej przy założeniu, że ekonomia sama z siebie doprowadzi do ich integracji, jest postępowaniem błędnym. Dowodem są tu ataki terrorystyczne, do których doszło w minionych latach w państwach Europy Zachodniej.

Jednostki i grupy społeczne od zawsze szukają w swych państwach ochrony przed takimi zagrożeniami jak obrażenia fizyczne, upadek gospodarczy czy utrata praw lub statusu społecznego. W społeczeństwach otwartych, charakteryzujących się odpowiednią kulturą organizacyjną, która zapewnia członkom społeczeństwa równość polityczną, imperatyw ten ma znaczenie fundamentalne. W przypadku wystąpienia deficytu tej równości między społeczeństwem a nowo przybyłymi migrantami nieuchronnie następuje jego podważenie i powstawanie przestrzeni emocjonalnej pustki wypełnionej niepewnością, a w konsekwencji politycznym wykluczeniem. Pojawia się wówczas miejsce na radykalną propagandę, która skłania do popełniania aktów terrorystycznych ${ }^{47}$. To zaś prowadzi do dalszego pogłębiania podziałów społecznych i wzmacniania warunków konfrontacji. Niwelowanie konfliktów społecznych, których przejawem są podziały, a rezultatem - ekstremizm i terroryzm, oznacza tworzenie, a zarazem stałe odtwarzanie zbiorowych tożsamości z udziałem migrantów. Obejmuje to jednostkową i zbiorową identyfikację, adaptację do liberalnych społeczeństw demokratycznych, de facto wspólnej egzystencji ludności lokalnej i napływowej w danym miejscu. Tylko wspólna formuła bytu kształtuje świadomość obu społeczności, tworząc z nich polityczną jedność w różnorodności.

nie ma pewnych właściwości dawnych. Tworzy nową indywidualność, a wszelkie odmienne indywidualności, nie będąc jednorodnymi, nie mogą należeć do tej samej serii ciągłej czy tym bardziej jedynej. Następstwa społeczeństw nie da się przedstawić w postaci linii geometrycznej, przypomina ono raczej drzewo, którego konary rosną w różnych kierunkach". E. Durkheim, Zasady metody socjologicznej, Wydawnictwo Naukowe PWN, Warszawa 1968, s. 47-48.

46 Tamże.

47 Wskazują ten aspekt sytuacyjny przykłady ataków terrorystycznych w Brukseli, Paryżu, Londynie, Berlinie i Sztokholmie. European Union terrorism situation and trend. Report 2017, European Union Agency for Law Enforcement Cooperation, 2019, s. 9-20. 


\section{Wybrane konsekwencje migracji dla bezpieczeństwa wspólnoty transatlantyckiej}

Ze zmianami demograficznymi w społeczeństwach państw wspólnoty transatlantyckiej zasilanych grupami migrantów, które wzmacniają obecne tam już społeczności pochodzące z zazwyczaj odległego obszaru, wiąże się kilka istotnych zagadnień. Fakt równości politycznej z dotychczasowymi członkami lokalnego społeczeństwa wymaga udzielenia odpowiedzi na kilka kluczowych pytań: Czy (a jeśli tak, to w jaki sposób) obecni członkowie społeczeństwa pochodzący z różnych społeczności rodzimych i imigrujących zaadaptowali się, jaką formułę związków społecznych tworzą, w jakim stopniu są zintegrowani lub dlaczego wzajemnie się izolują? W jaki sposób migranci, którzy po raz pierwszy pojawili się w danym państwie, powinni stawać się częścią wielokulturowego, otwartego społeczeństwa? Jaka powinna być formuła koegzystencji lokalnych i nowo przybyłych społeczności respektująca prawa i zasady wolności obywatelskich? Choć katalog pytań nie jest zamknięty, a odpowiedzi każdorazowo będą zasadniczo różne, to łączy je jeden wspólny mianownik - adaptacja i funkcjonowanie w obrębie otwartych społeczeństw demokratycznych, które mają określone podstawy aksjologiczne swojego funkcjonowania i projekcji rozwoju w czasie. W rezultacie chodzi o tworzenie określonych kompetencji społecznych, które pozwalają na eliminację radykalnych postaw oraz wprowadzanie dialogu jako formuły rozwiązywania konfliktów społecznych ${ }^{48}$.

Formuła dialogu jest i pozostaje wiążąca dla państw wspólnoty transatlantyckiej, stanowiąc centralny punkt odniesienia dla wszelkich rozważań i działań związanych z migracjami ludności. Nie może być przy tym kwestionowania w imię abstrakcyjnych założeń różnic kulturowych, cywilizacyjnych, religijnych czy też innych, które tworzą obszary aksjologicznego wykluczenia wspólnych wartości. Obiektywne istnienie związku między wolnością, równością i brakiem wykluczenia determinuje postać akceptacji społecznej lub jej braku wobec osób migrujących, a ponadto sposób ich przyjęcia oraz formy udzielanej im opieki i pomocy ${ }^{49}$. Pułapka aksjologicznego wyklucze-

48 M. Farnicka, M. Pocinho, What can psychology offer in cross-cultural dialogue. A psychological approach to intercultural competence, [w:] Cross-cultural dialogue..., s. 71-80.

49 T. Wunderlich, Bleakness and thin blankets: Bavaria's struggle with welcoming asylum seekers, „German Marshal Found of the United States” [online], 22 X 2014 [dostęp: $12 \mathrm{~V}$ 2018], dostępny w internecie: <http://www.gmfus.org/blog/2014/10/22/bleakness-and-thinblankets-bavaria $\%$ E2\%80\%99s-struggle-welcoming-asylum-seekers>. 
nia migrantów jest obecnie najważniejszym zagrożeniem dla bezpieczeństwa wewnętrznego państw tworzących wspólnotę transatlantycką.

Migracje stanowią rękojmię odpowiedniego podjęcia kwestii integracji i wykluczenia, a niekiedy być może dyskryminacji określanej przez postawy społeczne osób tworzących daną społeczność oraz nowo przybyłych. Ponadto wskazuje ona na uwarunkowania, które mogą prowadzić lub prowadzą do radykalizacji wskazanych grup społecznych, a w perspektywie czasu - przemocy, także pod postacią terroryzmu. Truizmem jest stwierdzenie, że w środowisku międzynarodowym prowadzenie właściwej polityki powinno się przekładać na wspólne podejście państw wspólnoty transatlantyckiej do działań w ramach organizacji międzynarodowych, przede wszystkim Organizacji Narodów Zjednoczonych i jej agend. Rzecz dotyczy działań zarówno na granicach zewnętrznych wspólnoty transatlantyckiej (europejskich i północnoamerykańskich), jak i w odleglejszych miejscach planety. Wiodącą kwestią jest $\mathrm{w}$ tym zakresie adaptacja istniejących lub skonstruowanie nowych długookresowych narzędzi: politycznych, ekonomicznych i prawnych, zarówno o charakterze wewnętrznym, jak i zewnętrznym. Powinny one gwarantować bezpieczeństwo i rozwój społeczny, ekonomiczny oraz polityczny państw wspólnoty transatlantyckiej, a także ich projekcję w czasie.

Braku konsensusu w sprawie migracji wśród państw wspólnoty transatlantyckiej można upatrywać $\mathrm{w}$ braku wzajemnego zrozumienia i porozumienia co do idei wspólnego interesu w tym zakresie. Nie występują w związku z tym wspólnie akceptowane formy i formuła migracji do państw Sojuszu Północnoatlantyckiego i Unii Europejskiej, czego rezultatem jest choćby odmienne podejście Stanów Zjednoczonych i Kanady oraz zachodnio- i wschodnioeuropejskich państw UE. Można to wiązać nie tylko z brakiem woli politycznej do działania, lecz przede wszystkim z niezrozumieniem, jaka wykładnia jest dla nich wspólna i powinna obowiązywać, w jakim zakresie i kogo dotyczyć oraz jakie procedury, mechanizmy i sposoby działania indywidualnego i zbiorowego powinny jej towarzyszyć. Opisany stan rzeczy wynika przede wszystkim z braku jasno określonych reguł zaangażowania politycznego wszystkich państw członkowskich. We wskazanym powyżej zakresie brakuje wspólnej - i spójnej - wykładni interesów narodowych, co stanowi nie tylko zasadniczą słabość w aspekcie kształtowania środowiska bezpieczeństwa $\mathrm{w}$ ramach państw wspólnoty transatlantyckiej, ale też rzutuje na wspólne podejście do zjawiska migracji ludności z obszarów do niej przyległych. 
W kontekście rozpatrywanej formuły związków politycznych zawartych w aksjologii jednymi z ważniejszych elementów związanych z migracjami ludności są przekaz medialny i komunikacja. W każdym społeczeństwie stanowią one centralny punkt odniesienia, oznaczają bowiem powiązanie tożsamości indywidualnej i zbiorowej z wpływem wywieranym przez instytucje państw demokratycznych. W ramach sieciocentrycznych społeczeństw poddawanych informacji i dezinformacji, którą traktuje się jako narzędzie walki politycznej, przekaz medialny i komunikacja stanowią rdzeń formuły przyjmowania migrantów, sposobów ich adaptacji i funkcjonowania w społeczeństwie otwartym ${ }^{50}$, a ponadto związanej z nimi wykładni, jak posługiwać się dostępnymi instrumentami wpływu politycznego, społecznego, kulturowego, ekonomicznego i innymi, by móc efektywniej niż dotychczas rozwiązywać zagadnienia związane z migrantami. Pewne jest, że nie ma takiej samej sytuacji oraz takiej samej formy migracji - każdorazowo są one inne. Nie powinno to jednak determinować woli ustanowienia wskazanych instrumentów, a także konsensusu co do ich zastosowania w praktyce.

Jak pokazały konflikty ukraiński, syryjski i północnoafrykański, ideologia i idee przemocy tworzone są wokół działań zinstytucjonalizowanych. Mogą to być zarówno działania informacyjne podmiotów pozapaństwowych (np. ISIS czy Hamasu), jak i państw (np. Rosji czy Iranu). W istocie stanowią dowód na instrumentalne traktowanie społeczności migrantów. Połączenie wielowarstwowych technik przekazu z działaniami na rzecz radykalizacji postaw społecznych stanowi obecnie jedno z wiodących narzędzi walki ideologicznej, szczególnie w przypadku Federacji Rosyjskiej, która dąży do osłabienia Zachodu, a w konsekwencji jego dezintegracji ${ }^{51}$. Zmanipulowany przekaz pozwala m.in. na wzniecanie i utrzymywanie niepokojów społecznych, których postać stosunkowo łatwo radykalizować w czasie. Myśląc i mówiąc o migracjach ludności do wysoko rozwiniętych państw zachodniego kręgu cywilizacyjnego, nie sposób pominąć tego kontekstu sytuacyjnego.

Wskazane powyżej zagadnienia są i pozostaną kluczowe, determinując pozostałe, w tym formę zaangażowania na rzecz nadania zjawisku określonej postaci oraz wzmocnienia humanitarnego wymiaru migracji ludności,

50 A. Juhász, P. Szicherle, The political effects of migration-related fake news, disinformation and conspiracy theories in Europe, Friedrich Ebert Stiftung, Political Capital Policy Research \& Consulting Institute, Budapest 2017, s. 15-19.

51 J. Darczewska, P. Żochowski, Środki aktywne. Rosyjski towar eksportowy, Ośrodek Studiów Wschodnich, Warszawa 2017 (Punkt Widzenia, 64), s. 73-74. 
a ponadto ładu wewnętrznego państw wspólnoty transatlantyckiej, form niesionej przez nie pomocy, zarówno w miejscu będącym źródłem migracji ludności (niezależnie od jej przyczyn), jak i w trakcie przemieszczania się jej do docelowego państwa wspólnoty transatlantyckiej. Na tym tle należy wskazać dwa wiodące problemy.

Pierwszym, mającym fundamentalne znaczenie dla bezpieczeństwa państw wspólnoty transatlantyckiej, są wzajemne zobowiązania, istniejące, tworzone i projektowane regulacje międzynarodowe. Udzielają one w tym zakresie odpowiedzi, lecz należy je traktować jako niepełne i niewystarczające, ponieważ jesteśmy obecnie dopiero na początku drogi do uregulowania sposobu podejścia do zjawiska migracji oraz określenia jego charakteru i znaczenia dla państw wspólnoty transatlantyckiej. Do tego, że dotychczasowa formuła okazała się niewystarczająca, nie trzeba nikogo przekonywać. Pytanie brzmi zatem: Jak postąpić, by w przyszłości unikać dezintegracji politycznej Zachodu, tak jak w przypadku Wielkiej Brytanii i brexitu, spowodowanego m.in. obawami o napływ nielegalnych migrantów (potęgowanymi przez doniesienia medialne z obozu uchodźców pod Calais), a zarazem chronić wartości humanitarne? Jak skonfigurować finansowe i prawne instrumenty polityki, by zredefiniować obecną formę zaangażowania europejskich państw NATO i UE? Jak stworzyć wykładnię zachowań politycznych budujących wzajemne zaufanie? Jaki modus vivendi przyjąć z państwami, przez które płynie migracja i w których ma ona źródło? Odpowiedzi na te pytania przesądzą o warunkach, w których odbywa się i będzie się odbywać migracja ludności, jak też o współdzieleniu związanych z nią kosztów politycznych, społecznych i ekonomicznych. Należy przy tym podkreślić, że dla państw wspólnoty transatlantyckiej nie ma alternatywy wobec przyjęcia wspólnej i spójnej wykładni. Decyduje o tym zjawisko TINA (there is no alternative) wzmocnione przykładem Wielkiej Brytanii.

Drugim, nie mniej istotnym problemem, są działania państw wspólnoty na forum ONZ i jej agend. 19 września 2016 r. Zgromadzenie Ogólne przyjęło deklarację z Nowego Jorku w sprawie uchodźców i imigrantów ${ }^{52}$, która przewiduje wdrożenie globalnej, spójnej, bezpiecznej, uporządkowanej i regularnej formuły migracji. Signum temporis dla państw wspólnoty transatlantyckiej jest wypracowanie wspólnego i co najistotniejsze spójnego podejścia do zjawiska migracji i usystematyzowanie go. Biorąc pod uwagę projekcję

52 New York declaration for refugees and migrants, United Nations General Assembly, A/ RES/71/1, 19 IX 2016. 
bezpieczeństwa wewnętrznego państw położonych po obu stronach Atlantyku, należy stwierdzić, że zasadniczą kwestią jest podjęcie zagadnienia migracji nie tylko w aspekcie niepokojów społecznych, no go zones czy terroryzmu ${ }^{53}$. Współpraca państw wspólnoty transatlantyckiej stanowi wymóg czasu i nie chodzi tylko o adaptację do nowych wyzwań, lecz także do nowej formuły środowiska bezpieczeństwa międzynarodowego. Obecne rozwiązania i działania państw wspólnoty transatlantyckiej należy ocenić jako doraźne, a nie kompleksowe i ukierunkowane na kształtowanie ich przyszłości. Procesy, z którymi państwa NATO i UE mierzą się w kontekście migracji, mają charakter globalny. Formuła ich działania ma przy tym podwójną postać - transatlantycką i regionalną, dowiązaną do przyległych obszarów. Podejmowane tu działania powinny być komplementarne, a obecnie takie nie są.

\section{Podsumowanie}

Podobnie jak minione stulecia, XXI w. charakteryzuje się głębokimi zmianami demograficznymi zachodzącymi w poszczególnych regionach naszej planety. Ich charakter oraz skutki są równie złożone jak kształt populacji ludzkich podlegających zmianom w czasie i przestrzeni. Dla obecnego stulecia w kształtowaniu tych procesów i nadawaniu im określonej postaci charakterystyczna jest rola techniki i technologii. Nigdy wcześniej nie była ona tak ważna w określaniu skali zjawiska, jego cech, wpływu, który wywiera, i wreszcie pożądanej postaci dla społeczeństw i decydentów politycznych. Zróżnicowanie polityczne państw wspólnoty transatlantyckiej jest przy tym decydującym czynnikiem w definiowaniu zmian demograficznych, towarzyszącej im narracji, określaniu postaw społecznych i politycznych jednostek, grup społecznych i wreszcie całych społeczeństw. Doświadczenia wieku XX ukazują przy tym, jak bardzo zjawisko zmian demograficznych związane jest z polityką bezpieczeństwa - zarówno tą wewnętrzną, właściwą państwu, jak i międzynarodową, prowadzoną z jego pośrednim lub bezpośrednim udziałem.

Wiek XXI kształtowany jest przez zjawiska, procesy, trendy i megatrendy występujące w przestrzeni społecznej, kulturowej, politycznej, ekonomicznej, militarnej oraz wielu innych. Ich zróżnicowana postać, zależna od regionu

53 D.S. Hamilton, Going beyond static understandings. Resilience must be shared, and it must be projected forward, [w:] Forward resilience protecting society in an interconnected world, ed. D. S. Hamilton, Washington DC 2016, s. 39-42. 
planety, determinuje odmienne koncepcje bezpieczeństwa i migracji. Tak jak w minionych stuleciach i tysiącleciach zasadniczymi zagadnieniami pozostają przy tym kwestie współpracy, rywalizacji i konfliktu między poszczególnymi państwami oraz ich społecznościami położonymi w różnych regionach na wielu kontynentach. Schemat ten, wpisany w postać ładu wewnętrznego i międzynarodowego, odgrywa podstawową rolę w geopolitycznych i geoekonomicznych zmianach zachodzących w państwach wspólnoty transatlantyckiej. Poprzez zmiany społeczne w tych krajach, dokonujące się w procesach migracji ludności, przeobrażają się nie tylko rynki pracy i rynki kapitałowe, ale także ekonomia polityczna, a wraz z nią formuła otwartych społeczeństw liberalnych.

Zjawisko przemian demograficznych w rodzimych populacjach zasilanych migracjami stanowi jeden z imperatywów myślenia o bezpieczeństwie transatlantyckim w XXI w. Dla wielu państw tworzących wspólnotę transatlantycką imperatyw ten ma szczególne znaczenie z uwagi na zróżnicowany wpływ, jaki na nie wywiera. W ich przypadku decydujące jest zarówno położenie geograficzne, jak i poziom rozwoju społecznego. Są one skonfrontowane $\mathrm{z}$ trendami i megatrendami społecznymi nadającymi postać zmianom w obszarze tożsamości, kultury i określonej formy cywilizacji. W tworzących NATO i Unię Europejską państwach demokratycznych o liberalnej formule organizacyjnej kluczowym zagadnieniem w XXI w. są procesy społeczne integrujące i dezintegrujące ich społeczeństwa. Rozdźwięk między pożądaną a faktyczną sytuacją poszczególnych państw NATO i Unii Europejskiej w tym zakresie tworzy nowy paradygmat ich bezpieczeństwa, określonej postaci ładu wewnętrznego i stabilności środowiska międzynarodowego. Paradygmat ten wymaga dalszych refleksji, w tym redefinicji i przewartościowania podejść, które wiążą się z migracjami ludności w XXI w.

\section{Bibliografia}

Abderrahim T., Pushing the boundaries. How to create more effective migration cooperation across the Mediterranean, European Council of Foreign Relations, January 2019 (Policy Brief).

Aggestam L., Hill Ch., The challenge of multiculturalism in European foreign policy, „International Affairs” 2008, vol. 84, issue 1.

Bin Laden's , letter to America”, „The Guardian” [online, dostęp: 22 V 2018], dostępny w internecie: <https://www.theguardian.com/world/2002/nov/24/theobserver>.

Bloemraad I., Korteweg A., Yurdakul G., Citizenship and immigration: multiculturalism, assimilation, and challenges to the nation-state, „Annual Review of Sociology” 2008, vol. 34, issue 1 . 
Bringing outsiders in. Transatlantic perspectives on immigrant political incorporation, ed. J.L. Hochschild, J.H. Mollenkopf, Cornell University Press, 2009.

Connectivity wars. Why migration, finance and trade are the geo-economic battlegrounds of the future, ed. M. Leonard, European Council of Foreign Relations, 2016.

Cross-cultural dialogue as a conflict management strategy, ed. J.M. Ramírez, G. Abad-Quintanal, Springer 2018.

Darczewska J., Żochowski P., Środki aktywne. Rosyjski towar eksportowy, Ośrodek Studiów Wschodnich, Warszawa 2017 (Punkt Widzenia, 64).

Delpech T., Powrót barbarzyństwa w XXI wieku, NADIR, Warszawa 2008.

Durkheim E., Zasady metody socjologicznej, Wydawnictwo Naukowe PWN, Warszawa 1968. The Eastern question Russia, the West, and Europe's grey zone, ed. D. S. Hamilton, S. Meister, Center for Transatlantic Relations, Washington DC 2016.

European Union terrorism situation and trend. Report 2017, European Union Agency for Law Enforcement Cooperation, 2019.

Farnicka M., Pocinho M., What can psychology offer in cross-cultural dialogue. A psychological approach to intercultural competence, [w:] Cross-cultural dialogue as a conflict management strategy, ed. J.M. Ramírez, G. Abad-Quintanal, Springer 2018.

Fiott D., Parkes R., Protecting Europe. The EU's response to hybrid threats, European Union Institute for Security Studies, April 2019 (Chaillot Paper, 151).

Forward resilience protecting society in an interconnected world, ed. D.S. Hamilton, Washington DC 2016.

Gasparini A. A., This is ot ou! Identity crisis in the $21^{\text {st }}$ century, [w:] ACHI 2018: The Eleventh International Conference on Advances in Computer-Human Interactions, IARIA, 2018.

Global migration indicators 2018, Global Migration Data Analysis Centre, International Organization for Migration, Berlin 2018.

Globalne podejście do kwestii migracji i mobilności, Komisja Europejska, KOM(2011) 743 wersja ostateczna, Bruksela, 18 XI 2011.

Gowan R., Bordering on crisis: Europe, Africa, and a new approach to crisis management, European Council of Foreign Relations, April 2017 (Policy Brief).

Greenhill K.M., The weaponisation of migration, [w:] Connectivity wars. Why migration, finance and trade are the geo-economic battlegrounds of the future, ed. M. Leonard, European Council of Foreign Relations, 2016.

Gryz J., Impact of terrorism on civic society: European Union's case study, „Scientific Journal of Internal Security and Civil Defence: Border Security and Management” 2018, No. 2 (7).

Hamilton D. S., Going beyond static understandings. Resilience must be shared, and it must be projected forward, [w:] Forward resilience protecting society in an interconnected world, ed. D. S. Hamilton, Washington DC 2016.

Herbst J.E., Forsaken territories? The emergence of Europe's grey zone and Western policy, [w:] The Eastern question Russia, the West, and Europe's grey zone, ed. D. S. Hamilton, S. Meister, Center for Transatlantic Relations, Washington DC 2016.

Hochschild J.L., Mollenkopf J.H., Modeling immigrant political incorporation, [w:] Bringing outsiders in. Transatlantic perspectives on immigrant political incorporation, ed. J.L. Hochschild, J.H. Mollenkopf, Cornell University Press, 2009.

Huntington S.P., The clash of civilizations?, „Foreign Affairs” 1993, vol. 72, No. 3. 
Joppke Ch., Successes and failures of Muslim integration in France and Germany, [w:] Bringing outsiders in. Transatlantic perspectives on immigrant political incorporation, ed. J.L. Hochschild, J.H. Mollenkopf, Cornell University Press, 2009.

Juhász A., Szicherle P., The political effects of migration-related fake news, disinformation and conspiracy theories in Europe, Friedrich Ebert Stiftung, Political Capital Policy Research \& Consulting Institute, Budapest 2017.

Kessels E., Nemr Ch., Countering violent extremism and development assistance identifying synergies, obstacles, and opportunities, Global Center on Cooperative Security, February 2016 (Policy Brief).

Kjær A.M., Rzadzenie, Sic!, Warszawa 2009.

Lebovich A., Halting ambition: EU migration and security policy in the Sahel, European Council of Foreign Relations, September 2018 (Policy Brief).

Lindhard T., The search for unity beneath our cultural differences, [w:] Cross-cultural dialogue as a conflict management strategy, ed. J.M. Ramírez, G. Abad-Quintanal, Springer 2018.

Macdonald S., Propaganda and information warfare in the twenty-first century. Altered images and deception operations, Routledge, London-New York 2007.

McNeil R., Migrants and the media: what shapes the narratives on immigration in different countries, „The Conversation”, 26 IV 2019.

Mandelbaum M., Migration and its discontents. The impacts of immigration: Europe vs. America, „The American Interest”, 13 VI 2018.

Menon A., Salter J.-P., Brexit: initial reflections, „International Affairs” 2016, vol. 92, issue 6.

Migration and 2030 Agenda. A guide for practitioners, International Organization for Migration, Geneva 2018.

Migration theory. Talking across disciplines, ed. C.B. Brettell, J.F. Hollifield, Routledge, New York-London 2013.

Multiple Futures Project. Navigating towards 2030. Final report, NATO, 2009.

New York declaration for refugees and migrants, United Nations General Assembly, A/RES/ 71/1, 19 IX 2016.

Nunn R., O’Donnell J., Shambaugh J., A dozen facts about immigration, The Hamilton Project, October 2018.

Parkes R., Nobody move! Myths of the EU migration crisis, EU Institute for Security Studies, December 2017 (Chaillot Papers, 143).

Payá-Santos C.A., Delgado-Morán J.J., Mazurier P. A., Individual terrorism as a response to the distorted phenomenon of cultural identity, [w:] Cross-cultural dialogue as a conflict management strategy, ed. J.M. Ramírez, G. Abad-Quintanal, Springer 2018.

Shear M.D., Jordan M., Fernandez M., The U.S. immigration system may have reached a breaking point, „The New York Times”, 10 IV 2019.

Strategic foresight analysis. 2017 Report, NATO, [b.m.r.w.].

Strik T., The global approach to migration and mobility, „Groningen Journal of International Law" 2017, vol 5, issue 2.

Stryker S., Burke P.J., The past, present, and future of an identity theory, „Social Psychology Quarterly" 2000, vol. 63, No. 4.

Swanson A., Trump's tariff threat sends Mexico, lawmakers and businesses scrambling, „The New York Times”, 31 V 2019. 
Transatlantic trends: mobility, migration, and integration. Key findings from 2014 and selected highlights from transatlantic trends and transatlantic trends. Immigration 2008-13, The German Marshall Fund of the United States, 2014.

World migration report 2018, International Organization for Migration, The UN Migration Agency, Geneva 2018.

World polulation by year, „Wordometers” [online, dostęp: 20 XI 2019], dostępny w internecie: $<$ http://www.worldometers.info/world-population/world-population-by-year/>.

Wunderlich T., Bleakness and thin blankets: Bavaria's struggle with welcoming asylum seekers, „German Marshal Found of the United States” [online], 22 X 2014 [dostęp: 12 V 2018], dostępny w internecie: <http://www.gmfus.org/blog/2014/10/22/ bleakness-and-thin-blankets-bavaria $\%$ E2\%80\%99s-struggle-welcoming-asylum-seekers $>$. 